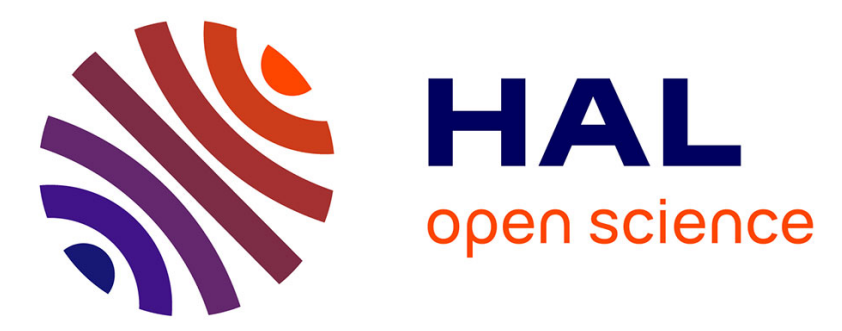

\title{
Risk of liquidity and contagion of the crisis on the US, UK and Euro Zone money markets
}

Bertrand Blancheton, Christian Bordes, Samuel Maveyraud, Philippe Rous

\section{To cite this version:}

Bertrand Blancheton, Christian Bordes, Samuel Maveyraud, Philippe Rous. Risk of liquidity and contagion of the crisis on the US, UK and Euro Zone money markets. International Journal of Finance and Economics, 2012, 17 (2), pp.124-146. 10.1002/ijfe.445 . hal-01098954

\section{HAL Id: hal-01098954 https://hal.science/hal-01098954}

Submitted on 30 Dec 2014

HAL is a multi-disciplinary open access archive for the deposit and dissemination of scientific research documents, whether they are published or not. The documents may come from teaching and research institutions in France or abroad, or from public or private research centers.
L'archive ouverte pluridisciplinaire HAL, est destinée au dépôt et à la diffusion de documents scientifiques de niveau recherche, publiés ou non, émanant des établissements d'enseignement et de recherche français ou étrangers, des laboratoires publics ou privés. 


\title{
Risk of liquidity and contagion of the crisis on the US, UK and Euro Zone money markets
}

\author{
Bertrand Blancheton ${ }^{1}$, GREThA UMR CNRS 5113 \\ UNIVERSITE MONTESQUIEU-BORDEAUX IV \\ Avenue Léon Duguit, 33608 Pessac, France
}

Christian Bordes ${ }^{2}$, Centre d'économie de la Sorbonne,

UNIVERSITE PARIS 1 PANTHEON-SORBONNE

106/112 Boulevard de l'Hôpital 75647 Paris Cedex 13, France

Samuel Maveyraud ${ }^{3}$, GREThA UMR CNRS 5113

UNIVERSITE MONTESQUIEU-BORDEAUX IV

Avenue Léon Duguit, 33608 Pessac, France

\author{
Philippe Rous ${ }^{4}$, LAPE \\ UNIVERSITE DE LIMOGES
}

5 rue Félix Eboué BP 3127, 87031 Limoges Cedex 1, France

\begin{abstract}
The financial crisis has produced a generalized rise of the liquidity risk on the money markets. The purpose of this article is to highlight the mechanisms of contagion between the money markets of the United States, the United Kingdom and the Euro Zone. To give an account of these mechanisms, a BEKK model, in which we introduce a structural break, is adopted. Thus, this model explicitly tests the spillover effects of the liquidity risk premium on money markets. The results show that before the financial crisis (i.e. the reference period), the spillover effects are observed on money markets, as a result of the interconnectedness of these markets, whereas over the crisis period, the liquidity problems go from the United Kingdom to the American money market and then to the euro area.
\end{abstract}

Code JEL: E4, G15, E58

\footnotetext{
${ }^{1}$ bertrand.blancheton@u-bordeaux4.fr

2 Chritian.bordes@u-paris1.fr

3 samuel.maveyraud@u-bordeaux4.fr

${ }^{4}$ Philippe.rous@unilim.fr
} 


\section{Introduction}

The upsurge of the financial crisis stems directly from the solvability crisis of the least well-off American households who took out subprime mortgages. From August 2007, the solvability crisis has turned into a bank liquidity crisis that has contributed to the spread of international upheaval. The bank liquidity issue has since appeared as the Gordian knot of the financial crisis (suspicion between financial institutions, credit restrictions, etc.).

This paper focuses on the major issue of liquidity on the money markets. It sets out to achieve two purposes. It seeks to analyse the dynamics of bank liquidity problems in the United States, the Euro Zone and the United Kingdom through the evolution of the interest rate spreads between LIBOR (London Interbank Offered Rate) and OIS (Overnight Index Swaps) on the different money markets. It aims to show the growing intensity of difficulties encountered by financial institutions in this matter. In an original way, this paper means to highlight the spreading process of strain on liquidity by testing potential causal connections between the spreads of the three money markets. By extension, it will attempt to reveal the truth about the causes of this liquidity crisis: did it too start in America? Did tensions in American money markets really spread to European markets as suggested by some authors: "This week a year ago, on 9 August 2007, a French investment house announced that it would suspend redemption of shares held by investors on a few of its enhanced-return euro money market funds. The reason for this move was that the market, for some of the paper in which these funds had invested, US-dollar denominated asset-backed commercial paper, had collapsed. With this announcement, the credit crisis - which was to broaden into a fullblown financial crisis - had started in earnest" (Deutsche Bank, Global Economic Perspectives, August 4, 2008). 
To shed light on these questions, the BEKK model, named after the bivariate model proposed by Baba et al. (1989) has been adopted. This model reveals in particular the spreading mechanisms governing the evolution of variances and covariances in discrepancies between LIBOR and OIS interest rates over time. The originality of our modelling lies with the introduction of a structural break in the equation of central tendency and equations of conditional variances and covariances (as proposed by Beirne et al., 2008). Taking this break into account - first exposed with the technique used by Westerlund (2006) - helps to explicitly test the potential modifications of the overspill phenomenon between money markets.

This article is organized in the following way: the second section analyses the meaning of the spreads of interest used, as well as their evolution between January 2007 and November 2008. The third section presents the adopted econometric model (BEKK with a structural break) and specifies the results obtained. Finally, the last section provides a conclusion to our study.

\section{Amplification of liquidity problems on money markets}

Banks make two types of banking operations on the money market to manage liquidity (or cash-flow): non-secured operations and repurchase transactions. These operations lead to risk-taking: credit risk (or counterparty risk) and liquidity risk (or market risk).

To deal with these risks, banks can resort to the derivatives market, in particular to the overnight index swaps market (OIS) in order to guard against events unforeseen by LIBOR, i.e. the unexpected degradation of the borrower situation and non-anticipated changes in liquidity demand addressed to the creditor and to the market (Kwan 2009), as well as CDS (credit default swap) to hedge against credit risk. 
Of these two types of risks, credit risk for non-secured operations and overnight index swaps operations is almost non-existent, these operations being of short maturity. Therefore, spread between LIBOR and OIS hardly reflects the credit risk premium. It thus mainly reveals the liquidity premium amount ${ }^{5}$. Indeed, the OIS is the fixed-leg rate in the coupon swap. The variable rate is an overnight rate; the interests from the variable leg are capitalized and are subjected to maturity payment in the same way as interests from the fixed-leg. The LIBOR is a cash rate in the sense that the creditor immediately releases (at contract signature) liquidities to transfer them to the borrower whereas there is no immediate cash released with the OIS (cash swap occurs at maturity providing there is a gap between rates). Consequently, the spread between LIBOR and OIS primarily reflects the intensity of bank liquidity problems.

In this paper, we will proceed to analyse three daily series of spread between LIBOR and OIS three months apart, in the United States, the Euro Zone ${ }^{6}$ and the United Kingdom.

[Figure 1]

During the first semester of 2007 before the financial crisis arose, spreads seemed quite stable, around 5-6 base points for the Euro Zone, 7-8 base points in the United States and 10 base points in the United Kingdom. None of these markets appeared to be the driving force for the overall dynamics of the three markets.

On August 9, 2007, the spread between LIBOR and OIS increased in all the markets. In the United States, it rose by 13 base points on the $8^{\text {th }}$ to 34 on the $9^{\text {th }}$ and 49 on the $10^{\text {th }}$. In the Euro Zone, it rose by a smaller proportion by 11 to 18 points and 27 points on the $10^{\text {th }}$. In the United Kingdom, the increase was even more moderate, from 20 to 25 then 32 points. This rise in liquidity price can be linked to upheavals that were then affecting the pricing system of sophisticated financial products. Indeed, the growing rise of uncertainty (and thus

\footnotetext{
${ }^{5}$ The discrepancy between IBOR and REPO from which is substracted the CDS discrepancy also helps to measure the liquidity premium. The liquidity premium thus obtained is very close to the IBOR-OIS discrepancy that we have adopted in this study. (cf. ECB, 2008, p. 144)

${ }^{6}$ For an analysis of the Euro Area money market we may refer to the article published by the ECB in February 2009.
} 
of the liquidity premium) came from the implementation of an increasingly complex securitization system that made risk pricing more and more difficult (Gonzalez-Paramo (2008); Zagaglia (2008)). As a result, the first American defaults warned operators that they were short of information for risks associated with these new financial products: they began to have doubts. On August 9, 2007, uncertainty was so acute that BNP-Paribas suspended the calculation of the net asset values of three of its funds.

From August 9, the European Central Bank reacted by injecting liquidities (€94.8 billion) and the Fed injected in turn $\$ 24$ billion. On August 13, both banks again injected $€ 48$ billion and $\$ 2$ billion respectively into banks. These measures had limited impact on the liquidity risk: the spread increased until September 12, 2007.

[Figure 2]

Over this period, the liquidity risk appeared to be more significant in the United States and the United Kingdom than in the Euro Zone, for the situation of banks in the Euro Zone appeared to offer better security against liquidity issues.

Subsequently, the liquidity risk fell in the United Kingdom by about 50 points: this fall could be related to the emergency aid granted on September 14 by the Bank of England to Northern Rock, the fifth largest bank in Great Britain. Spreads stabilized to similar levels between September 21 and November 14, 2007.

Spreads shot up again from November 15: the rise was halted on December 7 for the dollar, December 11 for the pound and December 7 for the euro. This reversal could be explained by the concerted support measure from five central banks (the European Central Bank, the Fed, the Bank of England, the Bank of Canada and the Bank of Switzerland) which injected liquidities on December 12. Over this period, as shown by the figure above, the euro spread seemed to lag behind the movements affecting the dollar and pound sterling. 
Spreads reached minimum levels on January 29 for the euro and the pound and on January 30 for the dollar. Subsequently, they rose until April 16 for the pound, April 30 for the dollar and May 14 for the euro. Then, until mid-September 2008, spreads stabilized around 70 base points. This relative stability was certainly linked to the support measures from the Fed and the American Treasury to help a number of the organisations in difficulty (Fannie Mae and Freddie Mac on July 13, 2008).

\section{[Figure 3]}

September 15, 2008 marked a break in the trajectory of liquidity risk. The announcement of the failure of Lehman Brothers (the fourth largest investment bank on Wall Street) led to a sharp rise in spreads. The "too big to fail" principle that seemed to be governing rescue actions from authorities on an international level was abandoned. It then put an end to the moral hazard induced by systematic rescue. This option made operators think that other institutions were not shielded from a similar sanction. After this episode, interbank loans were considered riskier, rates on money markets shot up and liquidity problems grew worse. Unsecured loans seemed frozen as suspicion became widespread amongst bankers. As shown in figure 3, the LIBOR-OIS spread soared after the failure of Lehman Brothers. It peaked on October 10 with 366 base points for the dollar and 194 base points for the euro. For the pound, the spread kept on increasing until November 6, 2008 (it then reached 298 base points), while it fell in the United States and stabilized in the Euro Zone. During this period of extreme tension, risk remained lower for the euro.

At the end of 2008, the problems of liquidity slowly decline so that we can consider, at the end of May, the return to a 'normal' situation, according to Fed Chairman Alan Greenspan (Bloomberg, May 26, 2009)

This description of the evolution of liquidity risk suggests that support from central banks had, at best, helped to stabilize the liquidity premium level rather than sharply reduce it. 
Each period of tension on money markets implied a long-term and cumulative rise between LIBOR and OIS. This hysteresis effect may be explained by the observed substitution between repurchase transactions and non-secured operations (LIBOR). Indeed, on money markets, repurchase transactions were preferred to non-secured actions as they naturally offer better security. Considering the increase of counterparty risk, it was more precisely repurchased transactions on Treasury bills that were preferred to non-secured transactions (without guaranty). Accordingly, the interest rate on repurchase transactions with Treasury bills security decreased so much that it dropped below the LIBOR or the OIS (Hördahl and King, 2008). The absorption of liquidity on the interbank market led to a rise in the LIBOR in such a way that the spread between the LIBOR and OIS rose.

The liquidity crisis associated with the financial crisis gives food for thought over the existence of contagion mechanisms that could have been set between the different money markets. We would like to determine more particularly, the extent to which the periods of strain on money markets in the Euro Zone and Great Britain together with the subsequent BCE and Bank of England's support actions, may be primarily explained by the rise in the liquidity risk on the American money market or whether the absorption of liquidity was simultaneous on the markets we are studying.

\section{Frame of analysis and findings}

To highlight the potential links between three variables $\mathrm{Y}_{1}, \mathrm{Y}_{2}$ and $\mathrm{Y}_{3}$, representing more specifically the daily variances in spread rates observed in the United States, the United Kingdom and the Euro Zone over the period from January 3, 2002 to June 22, 2009, the BEKK model with a structural break (Beirne et al., 2008) has been adopted. This model helps 
to evidence propagation mechanisms that govern the evolution of variances and covariances of these variables over time.

In order to bring to the fore the specificity of the contagion mechanism during the financial crisis, we distinguish two subperiods a "reference" period from January 3, 2002 to August 8, 2007 and the financial crisis period from August 9, 2007 to June 22, 2009.

Can the three series be directly modelized over this period with a muli-variate autoregressive BEKK-type model? To do so, unit-root tests must conclude with the rejection of $\mathrm{H}_{0}$ (chart 1). Yet, as shown by tests performed on level series (ADF test with constant) and over the period from January 3, 2002 to August 8, 2007, this hypothesis can never be rejected irrespective of the chronicle studied. However, over the financial crisis period, we have to reject the null hypothesis at a 5\% level: the spreads are non-stationnary.

\section{[Chart 1 here]}

Considering the acute increase of the spread that existed in money markets after the failure of Lehman Brothers, we introduce a structural break on September 15, 2008 over the financial crisis period.

We then proceed to the multivariate modelling of the three series. The model adopted is a trivariate BEKK model over the reference period and a trivariate BEKK model with 1 structural break over the financial crisis period. In matrix form, this last model is written:

\section{Equations of average values:}

$$
/ 1 / \quad \mathrm{Y}_{\mathrm{t}}=\Delta_{\mathrm{t}} \alpha+\left[\mathrm{I}-\Delta_{\mathrm{t}}\right] \beta+\phi \mathrm{Y}_{\mathrm{t}-1}+\varepsilon_{\mathrm{t}}
$$

Where $Y_{t}$ is a column vector with three components: $Y_{t}^{\prime}=\left[Y_{1 t}, Y_{2 t}, Y_{3 t}\right]$; $\alpha$ (resp. $\beta$ ) is likewise the column vector with three components: constants that prevail from September, 2008 (resp., before this date); $\phi$ is the supposed diagonal matrix of autoregressive coefficients 
to the order of one; finally, $\Delta_{\mathrm{t}}$ is an identity matrix of dimension 3 as from August 9, 2007 and nil before this date.

\section{Equations of conditional variances - covariances}

We set $\mathrm{H}_{\mathrm{t}}$ as the symmetrical matrix of conditional variances and covariances of $\varepsilon_{\mathrm{jt}}$ errors:

$$
\mathrm{H}_{\mathrm{t}}=\left[\begin{array}{lll}
\mathrm{h}_{11, \mathrm{t}} & \mathrm{h}_{12, \mathrm{t}} & \mathrm{h}_{13, \mathrm{t}} \\
\mathrm{h}_{12, \mathrm{t}} & \mathrm{h}_{22, \mathrm{t}} & \mathrm{h}_{23, \mathrm{t}} \\
\mathrm{h}_{13, \mathrm{t}} & \mathrm{h}_{23, \mathrm{t}} & \mathrm{h}_{33, \mathrm{t}}
\end{array}\right\rfloor
$$

Generically, we modelize these conditional variances and covariances as follows:

$$
\begin{aligned}
/ 2 / \quad \mathrm{H}_{\mathrm{t}} & =\mathrm{C}^{\prime} \Delta_{\mathrm{t}} \mathrm{C}+\mathrm{D}^{\prime}\left[\mathrm{I}-\Delta_{\mathrm{t}}\right] \mathrm{D}+ \\
+ & +\mathrm{A}^{\prime} \varepsilon_{\mathrm{t}} \Delta_{\mathrm{t}} \varepsilon_{\mathrm{t}}^{\prime} \mathrm{A}+\mathrm{B}^{\prime} \varepsilon_{\mathrm{t}}\left[\mathrm{I}-\Delta_{\mathrm{t}}\right] \varepsilon_{\mathrm{t}}^{\prime} \mathrm{B}+ \\
& +\mathrm{G}^{\prime} \mathrm{H}_{\mathrm{t}-1} \Delta_{\mathrm{t}} \mathrm{G}+\mathrm{F}^{\prime} \mathrm{H}_{\mathrm{t}-1}\left[\mathrm{I}-\Delta_{\mathrm{t}}\right] \mathrm{F}
\end{aligned}
$$

Considering the way the $\Delta_{\mathrm{t}}$ matrix is constructed, we note that the $\mathrm{C}, \mathrm{A}$ and $\mathrm{G}$ matrices are those of coefficients governing the evolutions of conditional variances - covariances from the structural break; matrices D, B and F are those prevailing before this break.

Matrices $\mathrm{C}$ and $\mathrm{D}$ have, whatever the hypothesis made subsequently on the propagation mechanism, a superior triangular structure:

$$
\mathrm{C}=\left[\begin{array}{ccc}
\mathrm{c}_{11} & \mathrm{c}_{12} & \mathrm{c}_{13} \\
0 & \mathrm{c}_{22} & \mathrm{c}_{23} \\
0 & 0 & \mathrm{c}_{33}
\end{array}\right] \quad \mathrm{D}=\left[\begin{array}{ccc}
\mathrm{d}_{11} & \mathrm{~d}_{12} & \mathrm{~d}_{13} \\
0 & \mathrm{~d}_{22} & \mathrm{~d}_{23} \\
0 & 0 & \mathrm{~d}_{33}
\end{array}\right]
$$

The structure of matrices $\mathrm{A}, \mathrm{B}, \mathrm{F}$ and $\mathrm{G}$ varies according to the hypothesis made on the spreading mechanism of volatility levels.

The "complete" model M1 introduces no restrictions on these volatilities propagation mechanisms: the conditional variance in zone $\mathrm{i}$ is determined not only by its own lag but also by those of conditional variances of other zones: 


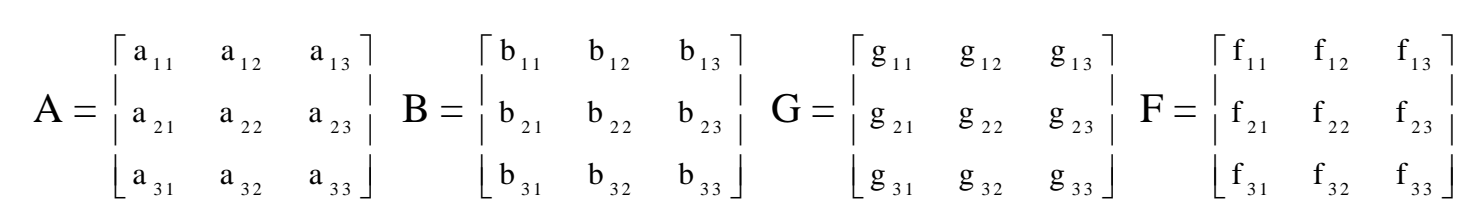

The "triangular" model $\mathrm{M} 2$ postulates an oriented propagation $\mathrm{Y}_{3} \rightarrow \mathrm{Y}_{2} \rightarrow \mathrm{Y}_{1}$. It is materialized by a restriction of nullity concerning the superior triangle of each $A, B, G$ and $F$ matrices:

$$
A=\left[\begin{array}{lll}
a_{11} & 0 & 0 \\
a_{21} & a_{22} & 0 \\
a_{31} & a_{32} & a_{33}
\end{array}\right] \quad B=\left[\begin{array}{lll}
b_{11} & 0 & 0 \\
b_{21} & b_{22} & 0 \\
b_{31} & b_{32} & b_{33}
\end{array}\right] \quad G=\left[\begin{array}{lll}
g_{11} & 0 & 0 \\
g_{21} & g_{22} & 0 \\
g_{31} & g_{32} & g_{33}
\end{array}\right] F=\left[\begin{array}{lll}
f_{11} & 0 & 0 \\
f_{21} & f_{22} & 0
\end{array}\right]
$$

According to this scheme, the conditional variance in zone 3 can only depend on its own lags while the one in zone 1 depends both on its own lag and on lags of the conditional variances of zones 2 and 3 .

Lastly, the "diagonal" model supposes that each variance and covariance never depends only on its own lags and squares or cross-products of corresponding lagged-innovations. The structure of matrices A, B, G and F is of a diagonal type:

$$
\mathrm{A}=\left[\begin{array}{ccc}
\mathrm{a}_{11} & 0 & 0 \\
0 & \mathrm{a}_{22} & 0 \\
0 & 0 & \mathrm{a}_{33}
\end{array}\right] \quad \mathrm{B}=\left[\begin{array}{ccc}
\mathrm{b}_{11} & 0 & 0 \\
0 & \mathrm{~b}_{22} & 0 \\
0 & 0 & \mathrm{~b}_{33}
\end{array}\right] \mathrm{G}=\left[\begin{array}{ccc}
\mathrm{g}_{11} & 0 & 0 \\
0 & \mathrm{~g}_{22} & 0 \\
0 & 0 & \mathrm{~g}_{33}
\end{array}\right] \mathrm{F}=\left[\begin{array}{ccc}
\mathrm{f}_{11} & 0 & 0 \\
0 & \mathrm{f}_{22} & 0 \\
0 & 0 & \mathrm{f}_{33}
\end{array}\right]
$$

The equations of variances and covariances associated with each of these three models are reproduced in annex 1 .

Chart 2 provides the values obtained for the log-likelihood function of the sample associated with the triangular model for each potential scheme of propagation over the two subperiods considered.

[Chart 2 here] 
From this table it ensues that if a "triangular"-type model should challenge the complete model, the UK $\rightarrow$ EuroZone $\rightarrow$ USA scheme would be favoured over the reference period. However, the UK $\rightarrow$ USA $\rightarrow$ EuroZone scheme would be adopted over the financial crisis period. It is thus on the basis of this scheme that several tests on various restrictions that may be added to coefficients and correspond to different propagation schemes ${ }^{7}$. More precisely, are tested:

- $\quad$ H0: model M2 versus $\mathrm{H}_{\mathrm{A}}$ : model M1

- $\quad \mathrm{H} 0$ : model M3 versus $\mathrm{H}_{\mathrm{A}}$ : model M2

[Chart 3 here]

We can firmly deduce that the "complete" model must be favoured over the reference period. However, the "triangular" model (UK $\rightarrow$ USA $\rightarrow$ EuroZone scheme) must be chosen over the financial crisis period.

These results must mainly be explained by the interconnectedness of banks' international balance sheets. Indeed, Banks' foreign positions have surged since 2000: the stock of foreign claims grew from $\$ 11$ trillion at end-2000 to $\$ 31$ trillion by mid-2007 (the year-on-year growth in foreign claims approached $30 \%$ by mid-2007) (Mc Guire and von Peter, 2009). Hence, over the reference period, this interconnectedness of banks' balance sheets implied a manifold propagation scheme.

Before the financial crisis period, the long position in dollar of UK banks, as foreign claims were predominantly in dollars: more than $\$ 300$ billion by mid-2007. UK banks maintained largely balanced net interbank US dollar positions (i.e. cross currency funding) (BIS, 2009). Hence, the liquidity problems on the British money market, primilarly due to an inadequate monetary policy as the BoE did not provide liquidity as fast and as much as the other central

\footnotetext{
${ }^{7}$ When these tests involve model M2, we always work with a "triangular" propagation scheme UK $\rightarrow$ EuroZone $\rightarrow$ USA over the reference period and UK $\rightarrow$ USA $\rightarrow$ EuroZone over the financial crisis period.
} 
banks, have mainly been propagated to the US money market and to a less extent to the euro money market. Furthermore, dislocations in FX swap markets over the financial crisis period made more expensive to obtain US dollars via currency swaps (Baba, N., Packer, F. (2008)) which has reinforced liquidity problems and the speed of contagion.

\section{Conclusion}

This paper, focused on the major issue of liquidity on money markets, has set out to highlight several phenomena and produce several findings. The analysis of the dynamics of bank liquidity issues in the United States, the Euro Zone and the United Kingdom through the evolution of the interest rate spread between LIBOR and OIS in various money markets indicates the growing intensity of the liquidity risk as suspicion grew between financial institutions. From this perspective, the failure of Lehman Brothers marked a break: after September 15, 2008 the price of liquidity shot up. Support actions from central banks only served to contain tensions around liquidity between August 2007 and September 2008 and they seemed overwhelmed by the growing distrust amongst financial institutions thereafter.

Then, in an original and novative manner, the article has highlighted the propagation process of the liquidity crisis by testing, with a trivariate BEKK model in which a break was introduced, the causal links between spreads in the three money markets. Tests could evidence the following results. Over the period of analysis chosen for the econometric study (i.e. from January 3, 2002 to June 22, 2009), we see that over the reference period (before the beginning of the financial crisis on August 9, 2007), the overspill between money markets was manifold: interest spreads interacted. Over the financial crisis period, the propagation scheme goes from the UK money maket to the US money market and then to the Euro money market: the bank liquidity crisis would not have come specifically from America but rather from the United Kingdom. 


\section{Bibliography}

ECB 2008. Financial Stability Review. European Central Bank - Eurosystem, December.

ECB 2009. Euro Money Market Study. European Central Bank - Eurosystem, February.

Baba Y., Engle R.F., Kraft D.F., Kroner, K.F. 1989. Multivariate simultaneous generalised Arch. Mimeo. Department of Economics, University of California, San Diego, USA.

Baba, N., Packer, F. (2008), Interpreting deviations from covered interest parity during the financial market turmoil of 2007-2008, BIS Working Papers 267.

Beirne J., Caporale G.M., Schulze-Ghattas M., Spagnolo N., 2008. Volatility Spillovers and Contagion from Mature to Emerging Stock Markets. IMF Working Paper 08/286.

Gonzalez-Paramo J. 2008. Financial Turmoil, Securitisation and Liquidity. Speech at the Global ABS Conference 2008, June 1.

Hordahl P. King M.R., 2008. Developments in repo markets during the financial turmoil. BIS Quarterly Review: 37-53.

Kwan S. 2009. Behavior of Libor in the Current Financial Crisis. FRBSF Economic Letter: 2009-04, January 23.

Mc Guire P., von Peter G., 2009. The US dollar shortage in global banking, BIS Quaterly Review, March.

Michaud F-L. Upper Ch., 2008. What drives interbank rates? Evidence from the Libor panel. BIS Quarterly Review: 47-58.

Westerlund J. 2006. Simple Unit Root Tests with Multiple Breaks. Mimeo. Lund University. Zagaglia P. 2008. Money-market segmentation in the euro area: what has changed during the turmoil? Bank of Finland Research, Discussion Paper 23/2008. 


\section{Annex 1: conditional variances and covariances in the different models}

\section{"Complete" model M1}

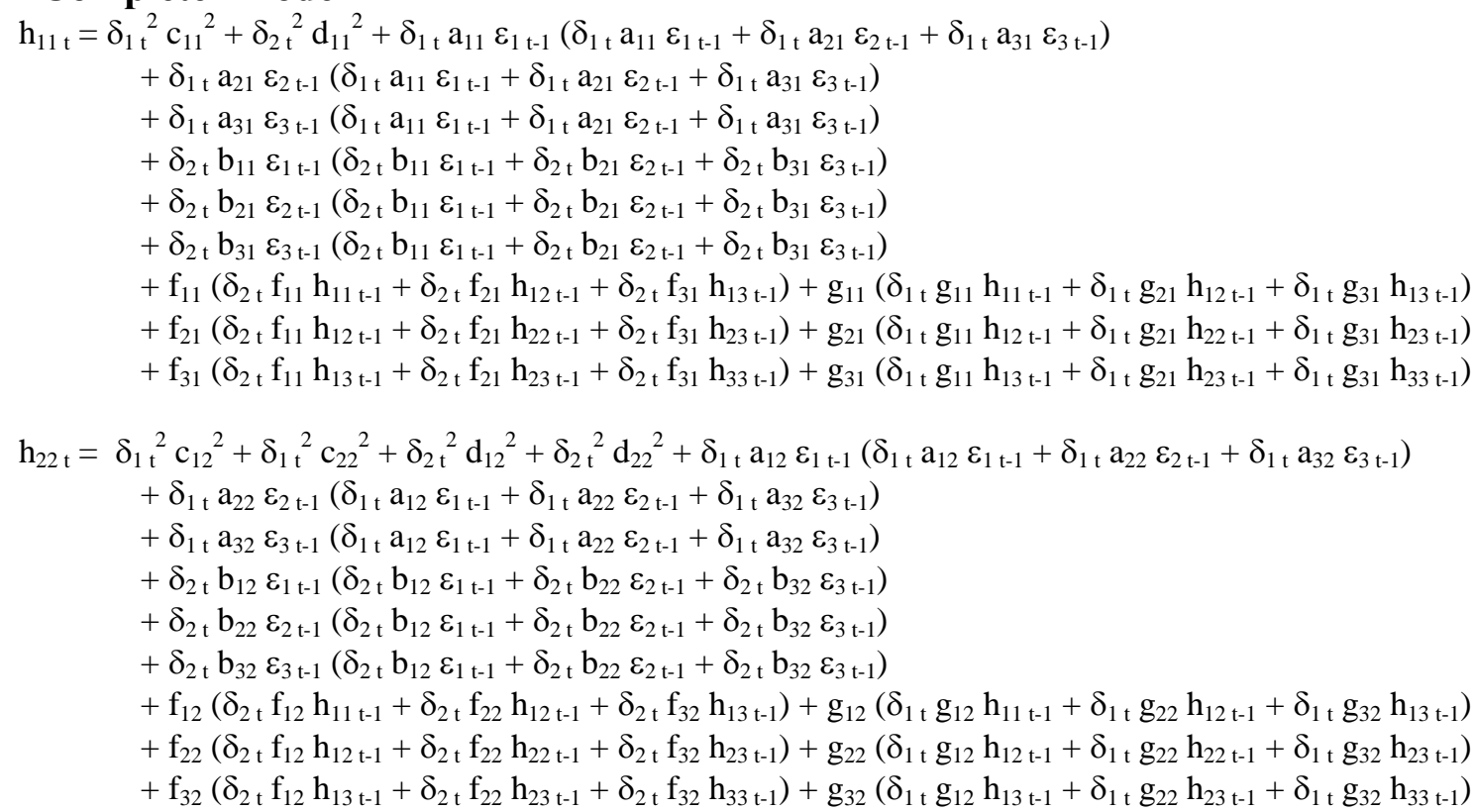

$\mathrm{h}_{33 \mathrm{t}}=\delta_{1 \mathrm{t}}{ }^{2} \mathrm{c}_{13}{ }^{2}+\delta_{1 \mathrm{t}}{ }^{2} \mathrm{c}_{23}{ }^{2}+\delta_{1 \mathrm{t}}{ }^{2} \mathrm{c}_{33}{ }^{2}+\delta_{2 \mathrm{t}}{ }^{2} \mathrm{~d}_{13}{ }^{2}+\delta_{2 \mathrm{t}}{ }^{2} \mathrm{~d}_{23}{ }^{2}+\delta_{2 \mathrm{t}}{ }^{2} \mathrm{~d}_{33}{ }^{2}$

$+\delta_{1 \mathrm{t}} \mathrm{a}_{13} \varepsilon_{1 \mathrm{t}-1}\left(\delta_{1 \mathrm{t}} \mathrm{a}_{13} \varepsilon_{1 \mathrm{t}-1}+\delta_{1 \mathrm{t}} \mathrm{a}_{23} \varepsilon_{2 \mathrm{t}-1}+\delta_{1 \mathrm{t}} \mathrm{a}_{33} \varepsilon_{3 \mathrm{t}-1}\right)$

$+\delta_{1 \mathrm{t}} \mathrm{a}_{23} \varepsilon_{2 \mathrm{t}-1}\left(\delta_{1 \mathrm{t}} \mathrm{a}_{13} \varepsilon_{1 \mathrm{t}-1}+\delta_{1 \mathrm{t}} \mathrm{a}_{23} \varepsilon_{2 \mathrm{t}-1}+\delta_{1 \mathrm{t}} \mathrm{a}_{33} \varepsilon_{3 \mathrm{t}-1}\right)$

$+\delta_{1 \mathrm{t}} \mathrm{a}_{33} \varepsilon_{3 \mathrm{t}-1}\left(\delta_{1 \mathrm{t}} \mathrm{a}_{13} \varepsilon_{1 \mathrm{t}-1}+\delta_{1 \mathrm{t}} \mathrm{a}_{23} \varepsilon_{2 \mathrm{t}-1}+\delta_{1 \mathrm{t}} \mathrm{a}_{33} \varepsilon_{3 \mathrm{t}-1}\right)$

$+\delta_{2 \mathrm{t}} \mathrm{b}_{13} \varepsilon_{1 \mathrm{t}-1}\left(\delta_{2 \mathrm{t}} \mathrm{b}_{13} \varepsilon_{1 \mathrm{t}-1}+\delta_{2 \mathrm{t}} \mathrm{b}_{23} \varepsilon_{2 \mathrm{t}-1}+\delta_{2 \mathrm{t}} \mathrm{b}_{33} \varepsilon_{3 \mathrm{t}-1}\right)$

$+\delta_{2 \mathrm{t}} \mathrm{b}_{23} \varepsilon_{2 \mathrm{t}-1}\left(\delta_{2 \mathrm{t}} \mathrm{b}_{13} \varepsilon_{1 \mathrm{t}-1}+\delta_{2 \mathrm{t}} \mathrm{b}_{23} \varepsilon_{2 \mathrm{t}-1}+\delta_{2 \mathrm{t}} \mathrm{b}_{33} \varepsilon_{3 \mathrm{t}-1}\right)$

$+\delta_{2 \mathrm{t}} \mathrm{b}_{33} \varepsilon_{3 \mathrm{t}-1}\left(\delta_{2 \mathrm{t}} \mathrm{b}_{13} \varepsilon_{1 \mathrm{t}-1}+\delta_{2 \mathrm{t}} \mathrm{b}_{23} \varepsilon_{2 \mathrm{t}-1}+\delta_{2 \mathrm{t}} \mathrm{b}_{33} \varepsilon_{3 \mathrm{t}-1}\right)$

$+\mathrm{f}_{13}\left(\delta_{2 \mathrm{t}} \mathrm{f}_{13} \mathrm{~h}_{11 \mathrm{t}-1}+\delta_{2 \mathrm{t}} \mathrm{f}_{23} \mathrm{~h}_{12 \mathrm{t}-1}+\delta_{2 \mathrm{t}} \mathrm{f}_{33} \mathrm{~h}_{13 \mathrm{t}-1}\right)+\mathrm{g}_{13}\left(\delta_{1 \mathrm{t}} \mathrm{g}_{13} \mathrm{~h}_{11 \mathrm{t}-1}+\delta_{1 \mathrm{t}} \mathrm{g}_{23} \mathrm{~h}_{12 \mathrm{t}-1}+\delta_{1 \mathrm{t}} \mathrm{g}_{33} \mathrm{~h}_{13 \mathrm{t}-1}\right)$

$+\mathrm{f}_{23}\left(\delta_{2 \mathrm{t}} \mathrm{f}_{13} \mathrm{~h}_{12 \mathrm{t}-1}+\delta_{2 \mathrm{t}} \mathrm{f}_{23} \mathrm{~h}_{22 \mathrm{t}-1}+\delta_{2 \mathrm{t}} \mathrm{f}_{33} \mathrm{~h}_{23 \mathrm{t}-1}\right)+\mathrm{g}_{23}\left(\delta_{1 \mathrm{t}} \mathrm{g}_{13} \mathrm{~h}_{12 \mathrm{t}-1}+\delta_{1 \mathrm{t}} \mathrm{g}_{23} \mathrm{~h}_{22 \mathrm{t}-1}+\delta_{1 \mathrm{t}} \mathrm{g}_{33} \mathrm{~h}_{23 \mathrm{t}-1}\right)$

$+\mathrm{f}_{33}\left(\delta_{2 \mathrm{t}} \mathrm{f}_{13} \mathrm{~h}_{13 \mathrm{t}-1}+\delta_{2 \mathrm{t}} \mathrm{f}_{23} \mathrm{~h}_{23 \mathrm{t}-1}+\delta_{2 \mathrm{t}} \mathrm{f}_{33} \mathrm{~h}_{33 \mathrm{t}-1}\right)+\mathrm{g}_{33}\left(\delta_{1 \mathrm{t}} \mathrm{g}_{13} \mathrm{~h}_{13 \mathrm{t}-1}+\delta_{1 \mathrm{t}} \mathrm{g}_{23} \mathrm{~h}_{23 \mathrm{t}-1}+\delta_{1 \mathrm{t}} \mathrm{g}_{33} \mathrm{~h}_{33 \mathrm{t}-1}\right)$

$\mathrm{h}_{12 \mathrm{t}}=\delta_{1 \mathrm{t}}^{2} \mathrm{c}_{11} \mathrm{c}_{12}+\delta_{2 \mathrm{t}}^{2} \mathrm{~d}_{11} \mathrm{~d}_{12}+\delta_{1 \mathrm{t}} \mathrm{a}_{12} \varepsilon_{1 \mathrm{t}-1}\left(\delta_{1 \mathrm{t}} \mathrm{a}_{11} \varepsilon_{1 \mathrm{t}-1}+\delta_{1 \mathrm{t}} \mathrm{a}_{21} \varepsilon_{2 \mathrm{t}-1}+\delta_{1 \mathrm{t}} \mathrm{a}_{31} \varepsilon_{3 \mathrm{t}-1}\right)$

$+\delta_{1 \mathrm{t}} \mathrm{a}_{22} \varepsilon_{2 \mathrm{t}-1}\left(\delta_{1 \mathrm{t}} \mathrm{a}_{11} \varepsilon_{1 \mathrm{t}-1}+\delta_{1 \mathrm{t}} \mathrm{a}_{21} \varepsilon_{2 \mathrm{t}-1}+\delta_{1 \mathrm{t}} \mathrm{a}_{31} \varepsilon_{3 \mathrm{t}-1}\right)$

$+\delta_{1 \mathrm{t}} \mathrm{a}_{32} \varepsilon_{3 \mathrm{t}-1}\left(\delta_{1 \mathrm{t}} \mathrm{a}_{11} \varepsilon_{1 \mathrm{t}-1}+\delta_{1 \mathrm{t}} \mathrm{a}_{21} \varepsilon_{2 \mathrm{t}-1}+\delta_{1 \mathrm{t}} \mathrm{a}_{31} \varepsilon_{3 \mathrm{t}-1}\right)$

$+\delta_{2 \mathrm{t}} \mathrm{b}_{12} \varepsilon_{1 \mathrm{t}-1}\left(\delta_{2 \mathrm{t}} \mathrm{b}_{11} \varepsilon_{1 \mathrm{t}-1}+\delta_{2 \mathrm{t}} \mathrm{b}_{21} \varepsilon_{2 \mathrm{t}-1}+\delta_{2 \mathrm{t}} \mathrm{b}_{31} \varepsilon_{3 \mathrm{t}-1}\right)$

$+\delta_{2 \mathrm{t}} \mathrm{b}_{22} \varepsilon_{2 \mathrm{t}-1}\left(\delta_{2 \mathrm{t}} \mathrm{b}_{11} \varepsilon_{1 \mathrm{t}-1}+\delta_{2 \mathrm{t}} \mathrm{b}_{21} \varepsilon_{2 \mathrm{t}-1}+\delta_{2 \mathrm{t}} \mathrm{b}_{31} \varepsilon_{3 \mathrm{t}-1}\right)$

$+\delta_{2 \mathrm{t}} \mathrm{b}_{32} \varepsilon_{3 \mathrm{t}-1}\left(\delta_{2 \mathrm{t}} \mathrm{b}_{11} \varepsilon_{1 \mathrm{t}-1}+\delta_{2 \mathrm{t}} \mathrm{b}_{21} \varepsilon_{2 \mathrm{t}-1}+\delta_{2 \mathrm{t}} \mathrm{b}_{31} \varepsilon_{3 \mathrm{t}-1}\right)$

$+\mathrm{f}_{12}\left(\delta_{2 \mathrm{t}} \mathrm{f}_{11} \mathrm{~h}_{11 \mathrm{t}-1}+\delta_{2 \mathrm{t}} \mathrm{f}_{21} \mathrm{~h}_{12 \mathrm{t}-1}+\delta_{2 \mathrm{t}} \mathrm{f}_{31} \mathrm{~h}_{13 \mathrm{t}-1}\right)+\mathrm{g}_{12}\left(\delta_{1 \mathrm{t}} \mathrm{g}_{11} \mathrm{~h}_{11 \mathrm{t}-1}+\delta_{1 \mathrm{t}} \mathrm{g}_{21} \mathrm{~h}_{12 \mathrm{t}-1}+\delta_{1 \mathrm{t}} \mathrm{g}_{31} \mathrm{~h}_{13 \mathrm{t}-1}\right)$

$+\mathrm{f}_{22}\left(\delta_{2 \mathrm{t}} \mathrm{f}_{11} \mathrm{~h}_{12 \mathrm{t}-1}+\delta_{2 \mathrm{t}} \mathrm{f}_{21} \mathrm{~h}_{22 \mathrm{t}-1}+\delta_{2 \mathrm{t}} \mathrm{f}_{31} \mathrm{~h}_{23 \mathrm{t}-1}\right)+\mathrm{g}_{22}\left(\delta_{1 \mathrm{t}} \mathrm{g}_{11} \mathrm{~h}_{12 \mathrm{t}-1}+\delta_{1 \mathrm{t}} \mathrm{g}_{21} \mathrm{~h}_{22 \mathrm{t}-1}+\delta_{1 \mathrm{t}} \mathrm{g}_{31} \mathrm{~h}_{23 \mathrm{t}-1}\right)$

$+f_{32}\left(\delta_{2 t} f_{11} h_{13 t-1}+\delta_{2 t} f_{21} h_{23 t-1}+\delta_{2 t} f_{31} h_{33 t-1}\right)+g_{32}\left(\delta_{1 t} g_{11} h_{13 t-1}+\delta_{1 t} g_{21} h_{23 t-1}+\delta_{1 t} g_{31} h_{33 t-1}\right)$

$\mathrm{h}_{13 \mathrm{t}}=\delta_{1 \mathrm{t}}{ }^{2} \mathrm{c}_{11} \mathrm{c}_{13}+\delta_{2 \mathrm{t}}{ }^{2} \mathrm{~d}_{11} \mathrm{~d}_{13}+\delta_{1 \mathrm{t}} \mathrm{a}_{13} \varepsilon_{1 \mathrm{t}-1}\left(\delta_{1 \mathrm{t}} \mathrm{a}_{11} \varepsilon_{1 \mathrm{t}-1}+\delta_{1 \mathrm{t}} \mathrm{a}_{21} \varepsilon_{2 \mathrm{t}-1}+\delta_{1 \mathrm{t}} \mathrm{a}_{31} \varepsilon_{3 \mathrm{t}-1}\right)$

$+\delta_{1 \mathrm{t}} \mathrm{a}_{23} \varepsilon_{2 \mathrm{t}-1}\left(\delta_{1 \mathrm{t}} \mathrm{a}_{11} \varepsilon_{1 \mathrm{t}-1}+\delta_{1 \mathrm{t}} \mathrm{a}_{21} \varepsilon_{2 \mathrm{t}-1}+\delta_{1 \mathrm{t}} \mathrm{a}_{31} \varepsilon_{3 \mathrm{t}-1}\right)$

$+\delta_{1 \mathrm{t}} \mathrm{a}_{33} \varepsilon_{3 \mathrm{t}-1}\left(\delta_{1 \mathrm{t}} \mathrm{a}_{11} \varepsilon_{1 \mathrm{t}-1}+\delta_{1 \mathrm{t}} \mathrm{a}_{21} \varepsilon_{2 \mathrm{t}-1}+\delta_{1 \mathrm{t}} \mathrm{a}_{31} \varepsilon_{3 \mathrm{t}-1}\right)$

$+\delta_{2 \mathrm{t}} \mathrm{b}_{13} \varepsilon_{1 \mathrm{t}-1}\left(\delta_{2 \mathrm{t}} \mathrm{b}_{11} \varepsilon_{1 \mathrm{t}-1}+\delta_{2 \mathrm{t}} \mathrm{b}_{21} \varepsilon_{2 \mathrm{t}-1}+\delta_{2 \mathrm{t}} \mathrm{b}_{31} \varepsilon_{3 \mathrm{t}-1}\right)$

$+\delta_{2 \mathrm{t}} \mathrm{b}_{23} \varepsilon_{2 \mathrm{t}-1}\left(\delta_{2 \mathrm{t}} \mathrm{b}_{11} \varepsilon_{1 \mathrm{t}-1}+\delta_{2 \mathrm{t}} \mathrm{b}_{21} \varepsilon_{2 \mathrm{t}-1}+\delta_{2 \mathrm{t}} \mathrm{b}_{31} \varepsilon_{3 \mathrm{t}-1}\right)$

$+\delta_{2 \mathrm{t}} \mathrm{b}_{33} \varepsilon_{3 \mathrm{t}-1}\left(\delta_{2 \mathrm{t}} \mathrm{b}_{11} \varepsilon_{1 \mathrm{t}-1}+\delta_{2 \mathrm{t}} \mathrm{b}_{21} \varepsilon_{2 \mathrm{t}-1}+\delta_{2 \mathrm{t}} \mathrm{b}_{31} \varepsilon_{3 \mathrm{t}-1}\right)$

$+\mathrm{f}_{13}\left(\delta_{2 \mathrm{t}} \mathrm{f}_{11} \mathrm{~h}_{11 \mathrm{t}-1}+\delta_{2 \mathrm{t}} \mathrm{f}_{21} \mathrm{~h}_{12 \mathrm{t}-1}+\delta_{2 \mathrm{t}} \mathrm{f}_{31} \mathrm{~h}_{13 \mathrm{t}-1}\right)+\mathrm{g}_{13}\left(\delta_{1 \mathrm{t}} \mathrm{g}_{11} \mathrm{~h}_{11 \mathrm{t}-1}+\delta_{1 \mathrm{t}} \mathrm{g}_{21} \mathrm{~h}_{12 \mathrm{t}-1}+\delta_{1 \mathrm{t}} \mathrm{g}_{31} \mathrm{~h}_{13 \mathrm{t}-1}\right)$

$+\mathrm{f}_{23}\left(\delta_{2 \mathrm{t}} \mathrm{f}_{11} \mathrm{~h}_{12 \mathrm{t}-1}+\delta_{2 \mathrm{t}} \mathrm{f}_{21} \mathrm{~h}_{22 \mathrm{t}-1}+\delta_{2 \mathrm{t}} \mathrm{f}_{31} \mathrm{~h}_{23 \mathrm{t}-1}\right)+\mathrm{g}_{23}\left(\delta_{1 \mathrm{t}} \mathrm{g}_{11} \mathrm{~h}_{12 \mathrm{t}-1}+\delta_{1 \mathrm{t}} \mathrm{g}_{21} \mathrm{~h}_{22 \mathrm{t}-1}+\delta_{1 \mathrm{t}} \mathrm{g}_{31} \mathrm{~h}_{23 \mathrm{t}-1}\right)$

$+\mathrm{f}_{33}\left(\delta_{2 \mathrm{t}} \mathrm{f}_{11} \mathrm{~h}_{13 \mathrm{t}-1}+\delta_{2 \mathrm{t}} \mathrm{f}_{21} \mathrm{~h}_{23 \mathrm{t}-1}+\delta_{2 \mathrm{t}} \mathrm{f}_{31} \mathrm{~h}_{33 \mathrm{t}-1}\right)+\mathrm{g}_{33}\left(\delta_{1 \mathrm{t}} \mathrm{g}_{11} \mathrm{~h}_{13 \mathrm{t}-1}+\delta_{1 \mathrm{t}} \mathrm{g}_{21} \mathrm{~h}_{23 \mathrm{t}-1}+\delta_{1 \mathrm{t}} \mathrm{g}_{31} \mathrm{~h}_{33 \mathrm{t}-1}\right)$

$\mathrm{h}_{23 \mathrm{t}}=\delta_{1 \mathrm{t}}^{2} \mathrm{c}_{12} \mathrm{c}_{13}+\delta_{1 \mathrm{t}}^{2} \mathrm{c}_{22} \mathrm{c}_{23}+\delta_{2 \mathrm{t}}^{2} \mathrm{~d}_{12} \mathrm{~d}_{13}+\delta_{2 \mathrm{t}}^{2} \mathrm{~d}_{22} \mathrm{~d}_{23}$

$+\delta_{1 \mathrm{t}} \mathrm{a}_{13} \varepsilon_{1 \mathrm{t}-1}\left(\delta_{1 \mathrm{t}} \mathrm{a}_{12} \varepsilon_{1 \mathrm{t}-1}+\delta_{1 \mathrm{t}} \mathrm{a}_{22} \varepsilon_{2 \mathrm{t}-1}+\delta_{1 \mathrm{t}} \mathrm{a}_{32} \varepsilon_{3 \mathrm{t}-1}\right)$ 
$+\delta_{1 \mathrm{t}} \mathrm{a}_{23} \varepsilon_{2 \mathrm{t}-1}\left(\delta_{1 \mathrm{t}} \mathrm{a}_{12} \varepsilon_{1 \mathrm{t}-1}+\delta_{1 \mathrm{t}} \mathrm{a}_{22} \varepsilon_{2 \mathrm{t}-1}+\delta_{1 \mathrm{t}} \mathrm{a}_{32} \varepsilon_{3 \mathrm{t}-1}\right)$

$+\delta_{1 \mathrm{t}} \mathrm{a}_{33} \varepsilon_{3 \mathrm{t}-1}\left(\delta_{1 \mathrm{t}} \mathrm{a}_{12} \varepsilon_{1 \mathrm{t}-1}+\delta_{1 \mathrm{t}} \mathrm{a}_{22} \varepsilon_{2 \mathrm{t}-1}+\delta_{1 \mathrm{t}} \mathrm{a}_{32} \varepsilon_{3 \mathrm{t}-1}\right)$

$+\delta_{2 \mathrm{t}} \mathrm{b}_{13} \varepsilon_{1 \mathrm{t}-1}\left(\delta_{2 \mathrm{t}} \mathrm{b}_{12} \varepsilon_{1 \mathrm{t}-1}+\delta_{2 \mathrm{t}} \mathrm{b}_{22} \varepsilon_{2 \mathrm{t}-1}+\delta_{2 \mathrm{t}} \mathrm{b}_{32} \varepsilon_{3 \mathrm{t}-1}\right)$

$+\delta_{2 \mathrm{t}} \mathrm{b}_{23} \varepsilon_{2 \mathrm{t}-1}\left(\delta_{2 \mathrm{t}} \mathrm{b}_{12} \varepsilon_{1 \mathrm{t}-1}+\delta_{2 \mathrm{t}} \mathrm{b}_{22} \varepsilon_{2 \mathrm{t}-1}+\delta_{2 \mathrm{t}} \mathrm{b}_{32} \varepsilon_{3 \mathrm{t}-1}\right)$

$+\delta_{2 \mathrm{t}} \mathrm{b}_{33} \varepsilon_{3 \mathrm{t}-1}\left(\delta_{2 \mathrm{t}} \mathrm{b}_{12} \varepsilon_{1 \mathrm{t}-1}+\delta_{2 \mathrm{t}} \mathrm{b}_{22} \varepsilon_{2 \mathrm{t}-1}+\delta_{2 \mathrm{t}} \mathrm{b}_{32} \varepsilon_{3 \mathrm{t}-1}\right)$

$+\mathrm{f}_{13}\left(\delta_{2 \mathrm{t}} \mathrm{f}_{12} \mathrm{~h}_{11 \mathrm{t}-1}+\delta_{2 \mathrm{t}} \mathrm{f}_{22} \mathrm{~h}_{12 \mathrm{t}-1}+\delta_{2 \mathrm{t}} \mathrm{f}_{32} \mathrm{~h}_{13 \mathrm{t}-1}\right)+\mathrm{g}_{13}\left(\delta_{1 \mathrm{t}} \mathrm{g}_{12} \mathrm{~h}_{11 \mathrm{t}-1}+\delta_{1 \mathrm{t}} \mathrm{g}_{22} \mathrm{~h}_{12 \mathrm{t}-1}+\delta_{1 \mathrm{t}} \mathrm{g}_{32} \mathrm{~h}_{13 \mathrm{t}-1}\right)$

$+\mathrm{f}_{23}\left(\delta_{2 \mathrm{t}} \mathrm{f}_{12} \mathrm{~h}_{12 \mathrm{t}-1}+\delta_{2 \mathrm{t}} \mathrm{f}_{22} \mathrm{~h}_{22 \mathrm{t}-1}+\delta_{2 \mathrm{t}} \mathrm{f}_{32} \mathrm{~h}_{23 \mathrm{t}-1}\right)+\mathrm{g}_{23}\left(\delta_{1 \mathrm{t}} \mathrm{g}_{12} \mathrm{~h}_{12 \mathrm{t}-1}+\delta_{1 \mathrm{t}} \mathrm{g}_{22} \mathrm{~h}_{22 \mathrm{t}-1}+\delta_{1 \mathrm{t}} \mathrm{g}_{32} \mathrm{~h}_{23 \mathrm{t}-1}\right)$

$+\mathrm{f}_{33}\left(\delta_{2 \mathrm{t}} \mathrm{f}_{12} \mathrm{~h}_{13 \mathrm{t}-1}+\delta_{2 \mathrm{t}} \mathrm{f}_{22} \mathrm{~h}_{23 \mathrm{t}-1}+\delta_{2 \mathrm{t}} \mathrm{f}_{32} \mathrm{~h}_{33 \mathrm{t}-1}\right)+\mathrm{g}_{33}\left(\delta_{1 \mathrm{t}} \mathrm{g}_{12} \mathrm{~h}_{13 \mathrm{t}-1}+\delta_{1 \mathrm{t}} \mathrm{g}_{22} \mathrm{~h}_{23 \mathrm{t}-1}+\delta_{1 \mathrm{t}} \mathrm{g}_{32} \mathrm{~h}_{33 \mathrm{t}-1}\right)$

\section{"Triangular" model M2}

$\mathrm{h}_{11 \mathrm{t}}=\delta_{1 \mathrm{t}}^{2} \mathrm{c}_{11}^{2}+\delta_{2 \mathrm{t}}^{2} \mathrm{~d}_{11}^{2}+\delta_{1 \mathrm{t}} \mathrm{a}_{11} \varepsilon_{1 \mathrm{t}-1}\left(\delta_{1 \mathrm{t}} \mathrm{a}_{11} \varepsilon_{1 \mathrm{t}-1}+\delta_{1 \mathrm{t}} \mathrm{a}_{21} \varepsilon_{2 \mathrm{t}-1}+\delta_{1 \mathrm{t}} \mathrm{a}_{31} \varepsilon_{3 \mathrm{t}-1}\right)$

$+\delta_{1 \mathrm{t}} \mathrm{a}_{21} \varepsilon_{2 \mathrm{t}-1}\left(\delta_{1 \mathrm{t}} \mathrm{a}_{11} \varepsilon_{1 \mathrm{t}-1}+\delta_{1 \mathrm{t}} \mathrm{a}_{21} \varepsilon_{2 \mathrm{t}-1}+\delta_{1 \mathrm{t}} \mathrm{a}_{31} \varepsilon_{3 \mathrm{t}-1}\right)$

$+\delta_{1 \mathrm{t}} \mathrm{a}_{31} \varepsilon_{3 \mathrm{t}-1}\left(\delta_{1 \mathrm{t}} \mathrm{a}_{11} \varepsilon_{1 \mathrm{t}-1}+\delta_{1 \mathrm{t}} \mathrm{a}_{21} \varepsilon_{2 \mathrm{t}-1}+\delta_{1 \mathrm{t}} \mathrm{a}_{31} \varepsilon_{3 \mathrm{t}-1}\right)$

$+\delta_{2 \mathrm{t}} \mathrm{b}_{11} \varepsilon_{1 \mathrm{t}-1}\left(\delta_{2 \mathrm{t}} \mathrm{b}_{11} \varepsilon_{1 \mathrm{t}-1}+\delta_{2 \mathrm{t}} \mathrm{b}_{21} \varepsilon_{2 \mathrm{t}-1}+\delta_{2 \mathrm{t}} \mathrm{b}_{31} \varepsilon_{3 \mathrm{t}-1}\right)$

$+\delta_{2 \mathrm{t}} \mathrm{b}_{21} \varepsilon_{2 \mathrm{t}-1}\left(\delta_{2 \mathrm{t}} \mathrm{b}_{11} \varepsilon_{1 \mathrm{t}-1}+\delta_{2 \mathrm{t}} \mathrm{b}_{21} \varepsilon_{2 \mathrm{t}-1}+\delta_{2 \mathrm{t}} \mathrm{b}_{31} \varepsilon_{3 \mathrm{t}-1}\right)$

$+\delta_{2 \mathrm{t}} \mathrm{b}_{31} \varepsilon_{3 \mathrm{t}-1}\left(\delta_{2 \mathrm{t}} \mathrm{b}_{11} \varepsilon_{1 \mathrm{t}-1}+\delta_{2 \mathrm{t}} \mathrm{b}_{21} \varepsilon_{2 \mathrm{t}-1}+\delta_{2 \mathrm{t}} \mathrm{b}_{31} \varepsilon_{3 \mathrm{t}-1}\right)$

$+\mathrm{f}_{11}\left(\delta_{2 \mathrm{t}} \mathrm{f}_{11} \mathrm{~h}_{11 \mathrm{t}-1}+\delta_{2 \mathrm{t}} \mathrm{f}_{21} \mathrm{~h}_{12 \mathrm{t}-1}+\delta_{2 \mathrm{t}} \mathrm{f}_{31} \mathrm{~h}_{13 \mathrm{t}-1}\right)+\mathrm{g}_{11}\left(\delta_{1 \mathrm{t}} \mathrm{g}_{11} \mathrm{~h}_{11 \mathrm{t}-1}+\delta_{1 \mathrm{t}} \mathrm{g}_{21} \mathrm{~h}_{12 \mathrm{t}-1}+\delta_{1 \mathrm{t}} \mathrm{g}_{31} \mathrm{~h}_{13 \mathrm{t}-1}\right)$

$+\mathrm{f}_{21}\left(\delta_{2 \mathrm{t}} \mathrm{f}_{11} \mathrm{~h}_{12 \mathrm{t}-1}+\delta_{2 \mathrm{t}} \mathrm{f}_{21} \mathrm{~h}_{22 \mathrm{t}-1}+\delta_{2 \mathrm{t}} \mathrm{f}_{31} \mathrm{~h}_{23 \mathrm{t}-1}\right)+\mathrm{g}_{21}\left(\delta_{1 \mathrm{t}} \mathrm{g}_{11} \mathrm{~h}_{12 \mathrm{t}-1}+\delta_{1 \mathrm{t}} \mathrm{g}_{21} \mathrm{~h}_{22 \mathrm{t}-1}+\delta_{1 \mathrm{t}} \mathrm{g}_{31} \mathrm{~h}_{23 \mathrm{t}-\mathrm{l}}\right)$

$+f_{31}\left(\delta_{2 t} f_{11} h_{13 t-1}+\delta_{2 t} f_{21} h_{23 t-1}+\delta_{2 t} f_{31} h_{33 t-1}\right)+g_{31}\left(\delta_{1 t} g_{11} h_{13 t-1}+\delta_{1 t} g_{21} h_{23 t-1}+\delta_{1 t} g_{31} h_{33 t-1}\right)$

$\mathrm{h}_{22 \mathrm{t}}=\delta_{1 \mathrm{t}}{ }^{2} \mathrm{c}_{12}{ }^{2}+\delta_{1 \mathrm{t}}{ }^{2} \mathrm{c}_{22}{ }^{2}+\delta_{2 \mathrm{t}}{ }^{2} \mathrm{~d}_{12}{ }^{2}+\delta_{2 \mathrm{t}}{ }^{2} \mathrm{~d}_{22}{ }^{2}+\delta_{1 \mathrm{t}} \mathrm{a}_{22} \varepsilon_{2 \mathrm{t}-1}\left(\delta_{1 \mathrm{t}} \mathrm{a}_{22} \varepsilon_{2 \mathrm{t}-1}+\delta_{1 \mathrm{t}} \mathrm{a}_{32} \varepsilon_{3 \mathrm{t}-1}\right)$

$+\delta_{1 \mathrm{t}} \mathrm{a}_{32} \varepsilon_{3 \mathrm{t}-1}\left(\delta_{1 \mathrm{t}} \mathrm{a}_{22} \varepsilon_{2 \mathrm{t}-1}+\delta_{1 \mathrm{t}} \mathrm{a}_{32} \varepsilon_{3 \mathrm{t}-1}\right)+\delta_{2 \mathrm{t}} \mathrm{b}_{22} \varepsilon_{2 \mathrm{t}-1}\left(\delta_{2 \mathrm{t}} \mathrm{b}_{22} \varepsilon_{2 \mathrm{t}-1}+\delta_{2 \mathrm{t}} \mathrm{b}_{32} \varepsilon_{3 \mathrm{t}-1}\right)$

$+\delta_{2 \mathrm{t}} \mathrm{b}_{32} \varepsilon_{3 \mathrm{t}-1}\left(\delta_{2 \mathrm{t}} \mathrm{b}_{22} \varepsilon_{2 \mathrm{t}-1}+\delta_{2 \mathrm{t}} \mathrm{b}_{32} \varepsilon_{3 \mathrm{t}-1}\right)$

$+\mathrm{f}_{22}\left(\delta_{2 \mathrm{t}} \mathrm{f}_{22} \mathrm{~h}_{22 \mathrm{t}-1}+\delta_{2 \mathrm{t}} \mathrm{f}_{32} \mathrm{~h}_{23 \mathrm{t}-1}\right)+\mathrm{g}_{22}\left(\delta_{1 \mathrm{t}} \mathrm{g}_{22} \mathrm{~h}_{22 \mathrm{t}-1}+\delta_{1 \mathrm{t}} \mathrm{g}_{32} \mathrm{~h}_{23 \mathrm{t}-1}\right)$

$+f_{32}\left(\delta_{2 t} f_{22} h_{23 t-1}+\delta_{2 t} f_{32} h_{33 t-1}\right)+g_{32}\left(\delta_{1 t} g_{22} h_{23 t-1}+\delta_{1 t} g_{32} h_{33 t-1}\right)$

$\mathrm{h}_{33 \mathrm{t}}=\delta_{1 \mathrm{t}}{ }^{2} \mathrm{c}_{13}{ }^{2}+\delta_{1 \mathrm{t}}{ }^{2} \mathrm{c}_{23}{ }^{2}+\delta_{1 \mathrm{t}}{ }^{2} \mathrm{c}_{33}{ }^{2}+\delta_{2 \mathrm{t}}{ }^{2} \mathrm{~d}_{13}{ }^{2}+\delta_{2 \mathrm{t}}{ }^{2} \mathrm{~d}_{23}{ }^{2}+\delta_{2 \mathrm{t}}{ }^{2} \mathrm{~d}_{33}{ }^{2}+\delta_{1 \mathrm{t}}{ }^{2} \mathrm{a}_{33}{ }^{2} \varepsilon_{3 \mathrm{t}-1}{ }^{2}$

$+\delta_{2 \mathrm{t}}{ }^{2} \mathrm{~b}_{33}{ }^{2} \varepsilon_{3 \mathrm{t}-1}{ }^{2}+\delta_{2 \mathrm{t}} \mathrm{f}_{33}{ }^{2} \mathrm{~h}_{33 \mathrm{t}-1}+\delta_{1 \mathrm{t}} \mathrm{g}_{33}{ }^{2} \mathrm{~h}_{33 \mathrm{t}-1}$

$\mathrm{h}_{12 \mathrm{t}}=\delta_{1 \mathrm{t}}{ }^{2} \mathrm{c}_{11} \mathrm{c}_{12}+\delta_{2 \mathrm{t}}^{2} \mathrm{~d}_{11} \mathrm{~d}_{12}+\delta_{1 \mathrm{t}} \mathrm{a}_{22} \varepsilon_{2 \mathrm{t}-1}\left(\delta_{1 \mathrm{t}} \mathrm{a}_{11} \varepsilon_{1 \mathrm{t}-1}+\delta_{1 \mathrm{t}} \mathrm{a}_{21} \varepsilon_{2 \mathrm{t}-1}+\delta_{1 \mathrm{t}} \mathrm{a}_{31} \varepsilon_{3 \mathrm{t}-1}\right)$

$+\delta_{1 \mathrm{t}} \mathrm{a}_{32} \varepsilon_{3 \mathrm{t}-1}\left(\delta_{1 \mathrm{t}} \mathrm{a}_{11} \varepsilon_{1 \mathrm{t}-1}+\delta_{1 \mathrm{t}} \mathrm{a}_{21} \varepsilon_{2 \mathrm{t}-1}+\delta_{1 \mathrm{t}} \mathrm{a}_{31} \varepsilon_{3 \mathrm{t}-1}\right)$

$+\delta_{2 \mathrm{t}} \mathrm{b}_{22} \varepsilon_{2 \mathrm{t}-1}\left(\delta_{2 \mathrm{t}} \mathrm{b}_{11} \varepsilon_{1 \mathrm{t}-1}+\delta_{2 \mathrm{t}} \mathrm{b}_{21} \varepsilon_{2 \mathrm{t}-1}+\delta_{2 \mathrm{t}} \mathrm{b}_{31} \varepsilon_{3 \mathrm{t}-1}\right)$

$+\delta_{2 \mathrm{t}} \mathrm{b}_{32} \varepsilon_{3 \mathrm{t}-1}\left(\delta_{2 \mathrm{t}} \mathrm{b}_{11} \varepsilon_{1 \mathrm{t}-1}+\delta_{2 \mathrm{t}} \mathrm{b}_{21} \varepsilon_{2 \mathrm{t}-1}+\delta_{2 \mathrm{t}} \mathrm{b}_{31} \varepsilon_{3 \mathrm{t}-1}\right)$

$+f_{22}\left(\delta_{2 \mathrm{t}} \mathrm{f}_{11} \mathrm{~h}_{12 \mathrm{t}-1}+\delta_{2 \mathrm{t}} \mathrm{f}_{21} \mathrm{~h}_{22 \mathrm{t}-1}+\delta_{2 \mathrm{t}} \mathrm{f}_{31} \mathrm{~h}_{23 \mathrm{t}-\mathrm{l})}\right)+\mathrm{g}_{22}\left(\delta_{1 \mathrm{t}} \mathrm{g}_{11} \mathrm{~h}_{12 \mathrm{t}-1}+\delta_{1 \mathrm{t}} \mathrm{g}_{21} \mathrm{~h}_{22 \mathrm{t}-1}+\delta_{1 \mathrm{t}} \mathrm{g}_{31} \mathrm{~h}_{23 \mathrm{t}-1}\right)$

$+f_{32}\left(\delta_{2 t} f_{11} h_{13 t-1}+\delta_{2 t} f_{21} h_{23 t-1}+\delta_{2 t} f_{31} h_{33 t-1}\right)+g_{32}\left(\delta_{1 t} g_{11} h_{13 t-1}+\delta_{1 t} g_{21} h_{23 t-1}+\delta_{1 t} g_{31} h_{33 t-1}\right)$

$\mathrm{h}_{13 \mathrm{t}}=\delta_{1 \mathrm{t}}{ }^{2} \mathrm{c}_{11} \mathrm{c}_{13}+\delta_{2 \mathrm{t}}{ }^{2} \mathrm{~d}_{11} \mathrm{~d}_{13}+\delta_{1 \mathrm{t}} \mathrm{a}_{33} \varepsilon_{3 \mathrm{t}-1}\left(\delta_{1 \mathrm{t}} \mathrm{a}_{11} \varepsilon_{1 \mathrm{t}-1}+\delta_{1 \mathrm{t}} \mathrm{a}_{21} \varepsilon_{2 \mathrm{t}-1}+\delta_{1 \mathrm{t}} \mathrm{a}_{31} \varepsilon_{3 \mathrm{t}-1}\right)$

$+\delta_{2 \mathrm{t}} \mathrm{b}_{33} \varepsilon_{3 \mathrm{t}-1}\left(\delta_{2 \mathrm{t}} \mathrm{b}_{11} \varepsilon_{1 \mathrm{t}-1}+\delta_{2 \mathrm{t}} \mathrm{b}_{21} \varepsilon_{2 \mathrm{t}-1}+\delta_{2 \mathrm{t}} \mathrm{b}_{31} \varepsilon_{3 \mathrm{t}-1}\right)$

$+f_{33}\left(\delta_{2 t} f_{11} h_{13 t-1}+\delta_{2 t} f_{21} h_{23 t-1}+\delta_{2 t} f_{31} h_{33 t-1}\right)+g_{33}\left(\delta_{1 t} g_{11} h_{13 t-1}+\delta_{1 t} g_{21} h_{23 t-1}+\delta_{1 t} g_{31} h_{33 t-1}\right)$

$\mathrm{h}_{23 \mathrm{t}}=\delta_{1 \mathrm{t}}{ }^{2} \mathrm{c}_{12} \mathrm{c}_{13}+\delta_{1 \mathrm{t}}{ }^{2} \mathrm{c}_{22} \mathrm{c}_{23}+\delta_{2 \mathrm{t}}{ }^{2} \mathrm{~d}_{12} \mathrm{~d}_{13}+\delta_{2 \mathrm{t}}{ }^{2} \mathrm{~d}_{22} \mathrm{~d}_{23}+\delta_{1 \mathrm{t}} \mathrm{a}_{33} \varepsilon_{3 \mathrm{t}-1}\left(\delta_{1 \mathrm{t}} \mathrm{a}_{22} \varepsilon_{2 \mathrm{t}-1}+\delta_{1 \mathrm{t}} \mathrm{a}_{32} \varepsilon_{3 \mathrm{t}-1}\right)$

$+\delta_{2 \mathrm{t}} \mathrm{b}_{33} \varepsilon_{3 \mathrm{t}-1}\left(\delta_{2 \mathrm{t}} \mathrm{b}_{22} \varepsilon_{2 \mathrm{t}-1}+\delta_{2 \mathrm{t}} \mathrm{b}_{32} \varepsilon_{3 \mathrm{t}-1}\right)$

$+f_{33}\left(\delta_{2 t} f_{22} h_{23 t-1}+\delta_{2 t} f_{32} h_{33 t-1}\right)+g_{33}\left(\delta_{1 t} g_{22} h_{23 t-1}+\delta_{1 t} g_{32} h_{33 t-1}\right)$

\section{"Diagonal" model M3}

$\mathrm{h}_{11 \mathrm{t}}=\delta_{1 \mathrm{t}}{ }^{2} \mathrm{c}_{11}{ }^{2}+\delta_{2 \mathrm{t}}{ }^{2} \mathrm{~d}_{11}{ }^{2}+\delta_{1 \mathrm{t}}{ }^{2} \mathrm{a}_{11}{ }^{2} \varepsilon_{1 \mathrm{t}-1}{ }^{2}+\delta_{2 \mathrm{t}}{ }^{2} \mathrm{~b}_{11}{ }^{2} \varepsilon_{1 \mathrm{t}-1}{ }^{2}+\delta_{2 \mathrm{t}} \mathrm{f}_{11}{ }^{2} \mathrm{~h}_{11 \mathrm{t}-1}+\delta_{1 \mathrm{t}} \mathrm{g}_{11}{ }^{2} \mathrm{~h}_{11 \mathrm{t}-1}$

$\mathrm{h}_{22 \mathrm{t}}=\delta_{1 \mathrm{t}}{ }^{2} \mathrm{c}_{12}{ }^{2}+\delta_{1 \mathrm{t}}{ }^{2} \mathrm{c}_{22}{ }^{2}+\delta_{2 \mathrm{t}}{ }^{2} \mathrm{~d}_{12}{ }^{2}+\delta_{2 \mathrm{t}}{ }^{2} \mathrm{~d}_{22}{ }^{2}+\delta_{1 \mathrm{t}}{ }^{2} \mathrm{a}_{22}{ }^{2} \varepsilon_{2 \mathrm{t}-1}{ }^{2}+\delta_{2 \mathrm{t}}{ }^{2} \mathrm{~b}_{22}{ }^{2} \varepsilon_{2 \mathrm{t}-1}{ }^{2}+\delta_{2 \mathrm{t}} \mathrm{f}_{22}{ }^{2} \mathrm{~h}_{22 \mathrm{t}-1}+\delta_{1 \mathrm{t}} \mathrm{g}_{22}{ }^{2} \mathrm{~h}_{22 \mathrm{t}-1}$

$\mathrm{h}_{33 \mathrm{t}}=\delta_{1 \mathrm{t}}{ }^{2} \mathrm{c}_{13}{ }^{2}+\delta_{1 \mathrm{t}}{ }^{2} \mathrm{c}_{23}{ }^{2}+\delta_{1 \mathrm{t}}{ }^{2} \mathrm{c}_{33}{ }^{2}+\delta_{2 \mathrm{t}}{ }^{2} \mathrm{~d}_{13}{ }^{2}+\delta_{2 \mathrm{t}}{ }^{2} \mathrm{~d}_{23}{ }^{2}+\delta_{2 \mathrm{t}}{ }^{2} \mathrm{~d}_{33}{ }^{2}+\delta_{1 \mathrm{t}}{ }^{2} \mathrm{a}_{33}{ }^{2} \varepsilon_{3 \mathrm{t}-1}{ }^{2}+\delta_{2 \mathrm{t}}{ }^{2} \mathrm{~b}_{33}{ }^{2} \varepsilon_{3 \mathrm{t}-1}{ }^{2}$

$+\delta_{2 \mathrm{t}} \mathrm{f}_{33}{ }^{2} \mathrm{~h}_{33 \mathrm{t}-1}+\delta_{1 \mathrm{t}} \mathrm{g}_{33}{ }^{2} \mathrm{~h}_{33 \mathrm{t}-1}$

$\mathrm{h}_{12 \mathrm{t}}=\delta_{1 \mathrm{t}}{ }^{2} \mathrm{c}_{11} \mathrm{c}_{12}+\delta_{2 \mathrm{t}}{ }^{2} \mathrm{~d}_{11} \mathrm{~d}_{12}+\delta_{1 \mathrm{t}}{ }^{2} \mathrm{a}_{11} \mathrm{a}_{22} \varepsilon_{1 \mathrm{t}-1} \varepsilon_{2 \mathrm{t}-1}+\delta_{2 \mathrm{t}}{ }^{2} \mathrm{~b}_{11} \mathrm{~b}_{22} \varepsilon_{1 \mathrm{t}-1} \varepsilon_{2 \mathrm{t}-1}+\delta_{2 \mathrm{t}} \mathrm{f}_{11} \mathrm{f}_{22} \mathrm{~h}_{12 \mathrm{t}-1}+\delta_{1 \mathrm{t}} \mathrm{g}_{11} \mathrm{~g}_{22} \mathrm{~h}_{12 \mathrm{t}-1}$

$\mathrm{h}_{13 \mathrm{t}}=\delta_{1 \mathrm{t}}{ }^{2} \mathrm{c}_{11} \mathrm{c}_{13}+\delta_{2 \mathrm{t}}{ }^{2} \mathrm{~d}_{11} \mathrm{~d}_{13}+\delta_{1 \mathrm{t}}{ }^{2} \mathrm{a}_{11} \mathrm{a}_{33} \varepsilon_{1 \mathrm{t}-1} \varepsilon_{3 \mathrm{t}-1}+\delta_{2 \mathrm{t}}{ }^{2} \mathrm{~b}_{11} \mathrm{~b}_{33} \varepsilon_{1 \mathrm{t}-1} \varepsilon_{3 \mathrm{t}-1}+\delta_{2 \mathrm{t}} \mathrm{f}_{11} \mathrm{f}_{33} \mathrm{~h}_{13 \mathrm{t}-1}+\delta_{1 \mathrm{t}} \mathrm{g}_{11} \mathrm{~g}_{33} \mathrm{~h}_{13 \mathrm{t}-1}$ 
$\mathrm{h}_{23 \mathrm{t}}=\delta_{1 \mathrm{t}}{ }^{2} \mathrm{c}_{12} \mathrm{c}_{13}+\delta_{1 \mathrm{t}}{ }^{2} \mathrm{c}_{22} \mathrm{c}_{23}+\delta_{2 \mathrm{t}}{ }^{2} \mathrm{~d}_{12} \mathrm{~d}_{13}+\delta_{2 \mathrm{t}}{ }^{2} \mathrm{~d}_{22} \mathrm{~d}_{23}+\delta_{1 \mathrm{t}}{ }^{2} \mathrm{a}_{22} \mathrm{a}_{33} \varepsilon_{2 \mathrm{t}-1} \varepsilon_{3 \mathrm{t}-1}+\delta_{2 \mathrm{t}}{ }^{2} \mathrm{~b}_{22} \mathrm{~b}_{33} \varepsilon_{2 \mathrm{t}-1} \varepsilon_{3 \mathrm{t}-1}+\delta_{2 \mathrm{t}} \mathrm{f}_{22}$ $\mathrm{f}_{33} \mathrm{~h}_{23 \mathrm{t}-1}+\delta_{1 \mathrm{t}} \mathrm{g}_{22} \mathrm{~g}_{33} \mathrm{~h}_{23 \mathrm{t}-1}$ 
Chart 1

Unit-root tests (ADF) for each series of spreads (From)

Period:

Period:

January 2, 2002

August 9, 2007

to August 8, 2007 to June 22, 2009

\begin{tabular}{ccccc}
\hline \hline & t-Statistic & Prob. & t-Statistic & Prob. \\
\hline Spread_us_3M & -4.24 & 0.00 & -2.02 & 0.28 \\
Spread_euro_3M & -4.74 & 0.00 & -2.40 & 0.14 \\
Spread_bp_3M & -6.00 & 0.00 & -1.97 & 0.30 \\
\hline \hline
\end{tabular}

Unit-root tests: the number of lags is automatically determined on the basis of the Min(SIC) criterion. The Prob.column provides the risk threshold from which it becomes possible to reject $\mathrm{HO}$ 
Chart 2

Log likelihood function of the "triangular" type BEKK model

\begin{tabular}{lcc}
\hline \hline Propagation scheme & Log L \\
\hline \hline & $\begin{array}{c}\text { Period: } \\
\text { January 2, 2002 } \\
\text { to August 9, 2007 }\end{array}$ & $\begin{array}{c}\text { Period: } \\
\text { August 10, 2007 } \\
\text { to June 22, 2009 }\end{array}$ \\
\hline $\mathrm{USA} \rightarrow$ EURO $\rightarrow$ UK & 12991.8 & 959.1582 \\
$\mathrm{USA} \rightarrow$ UK $\rightarrow$ EURO & 13292.98 & 1054.25 \\
$\mathrm{EURO} \rightarrow$ USA $\rightarrow$ UK & 12590.62 & 960.5722 \\
$\mathrm{EURO} \rightarrow$ UK $\rightarrow$ USA & 13018.38 & 1849.287 \\
$\mathrm{UK} \rightarrow$ USA $\rightarrow$ EURO & 13297.23 & 1989.113 \\
$\mathrm{UK} \rightarrow$ EURO $\rightarrow$ USA & 13337.91 & 1912.941 \\
\hline \hline
\end{tabular}


Chart 3

Tests on restrictions that may be added to the different models

\begin{tabular}{lllllll}
\hline \hline & \multicolumn{2}{c}{$\begin{array}{c}\text { Period: } \\
\text { January 2, 2002 } \\
\text { to August 8, 2007 }\end{array}$} & $\begin{array}{l}\text { Period: } \\
\text { August 10, 2007 } \\
\text { to June 22, 2009 }\end{array}$ & \\
\hline \hline $\begin{array}{l}\text { Null } \\
\text { hypothesis }\end{array}$ & $\begin{array}{l}\text { Alternative } \\
\text { hyp. }\end{array}$ & $\begin{array}{l}\text { Chi2 }- \\
\text { Stat }\end{array}$ & $\begin{array}{l}\mathrm{P}- \\
\text { Value }\end{array}$ & $\begin{array}{l}\text { Chi2 }- \\
\text { Stat }\end{array}$ & $\begin{array}{l}\mathrm{P}- \\
\text { Value }\end{array}$ & $\begin{array}{l}\text { Restrictions : nullity of } \\
\text { coefficients }\end{array}$ \\
\hline $\begin{array}{l}\text { M2 } \\
\text { (triangular) }\end{array}$ & $\begin{array}{l}\text { M1 } \\
\text { (complete) }\end{array}$ & 22.57 & 0.001 & 12.87 & 0.17 & $\mathrm{a}_{12}, \mathrm{a}_{13}, \mathrm{a}_{23}, \mathrm{~b}_{12}, \mathrm{~b}_{13}, \mathrm{~b}_{23}, \mathrm{~g}_{12}, \mathrm{~g}_{13}$, \\
$\begin{array}{l}\text { M3 } \\
\text { (diagonal) }\end{array}$ & $\begin{array}{l}\text { M2 } \\
\text { (triangular) }\end{array}$ & 11.35 & 0.0781 & 135.77 & 0.00 & $\begin{array}{l}\mathrm{g}_{23}, \mathrm{f}_{12}, \mathrm{f}_{13}, \mathrm{f}_{23} \\
\mathrm{~g}_{32}, \mathrm{f}_{21}, \mathrm{f}_{31}, \mathrm{f}_{32}, \mathrm{f}_{31}, \mathrm{~b}_{32}, \mathrm{~g}_{21}, \mathrm{~g}_{31},\end{array}$ \\
\hline \hline
\end{tabular}


Figure 1:

Spreads between the LIBOR and OIS over the whole period

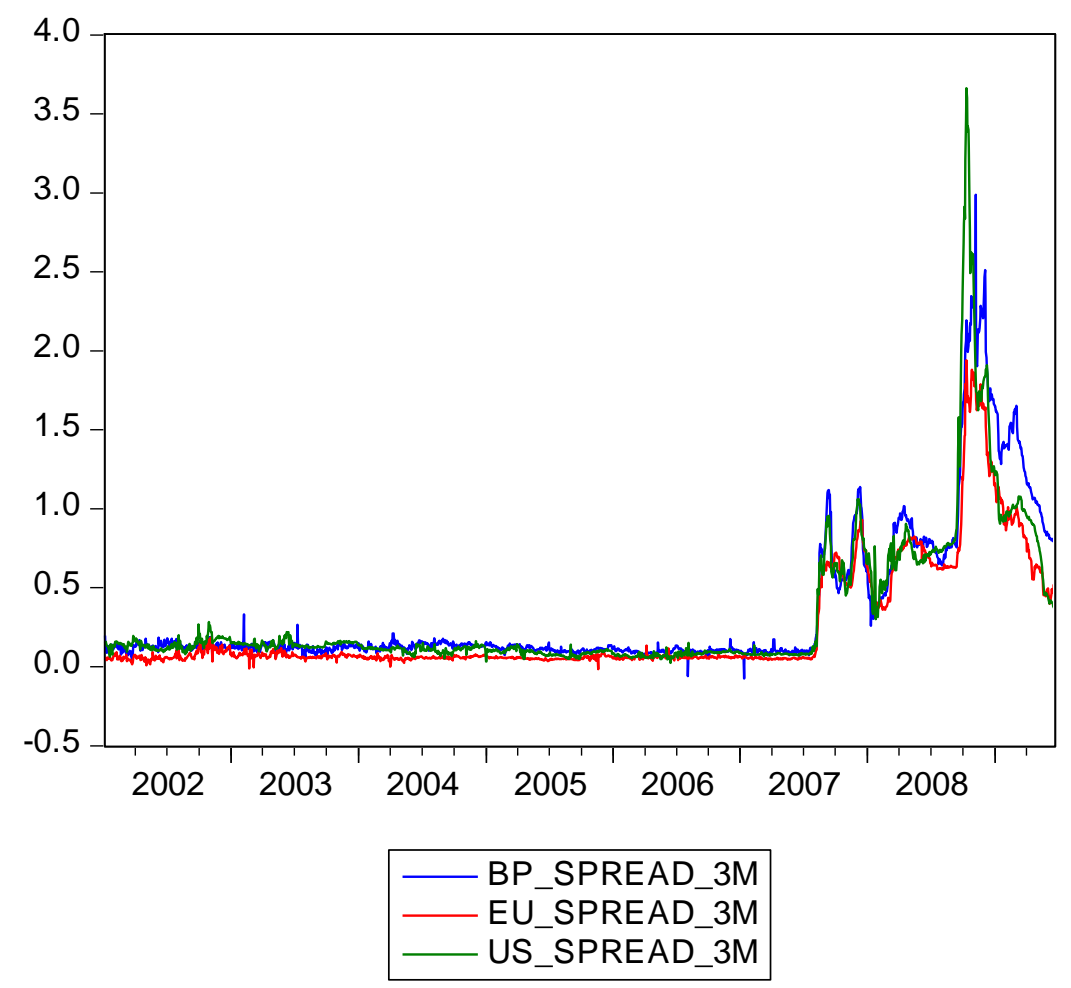


Figure 2:

Spreads between the LIBOR and OIS between January 3, 2002 and August 8, 2007

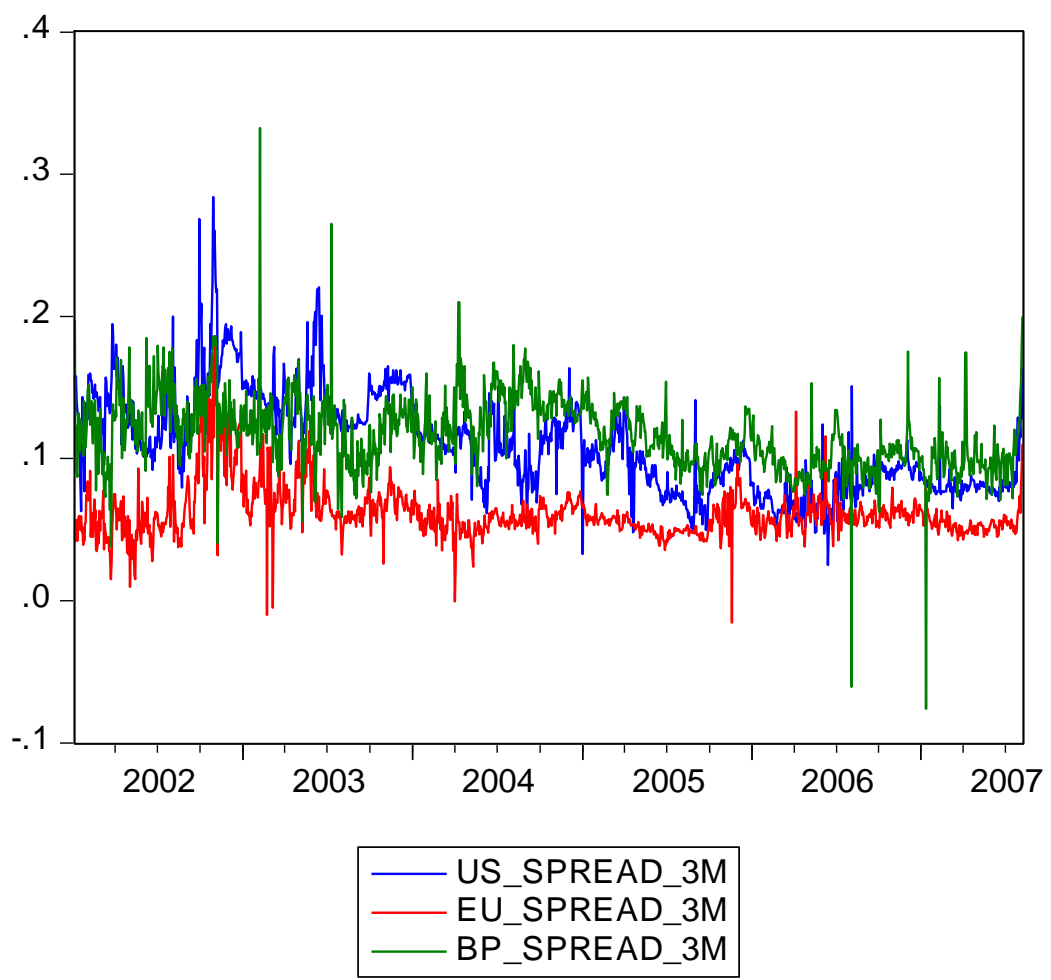


Figure 3:

Spreads between the LIBOR and OIS between August 9, 2007 and June 22, 2008

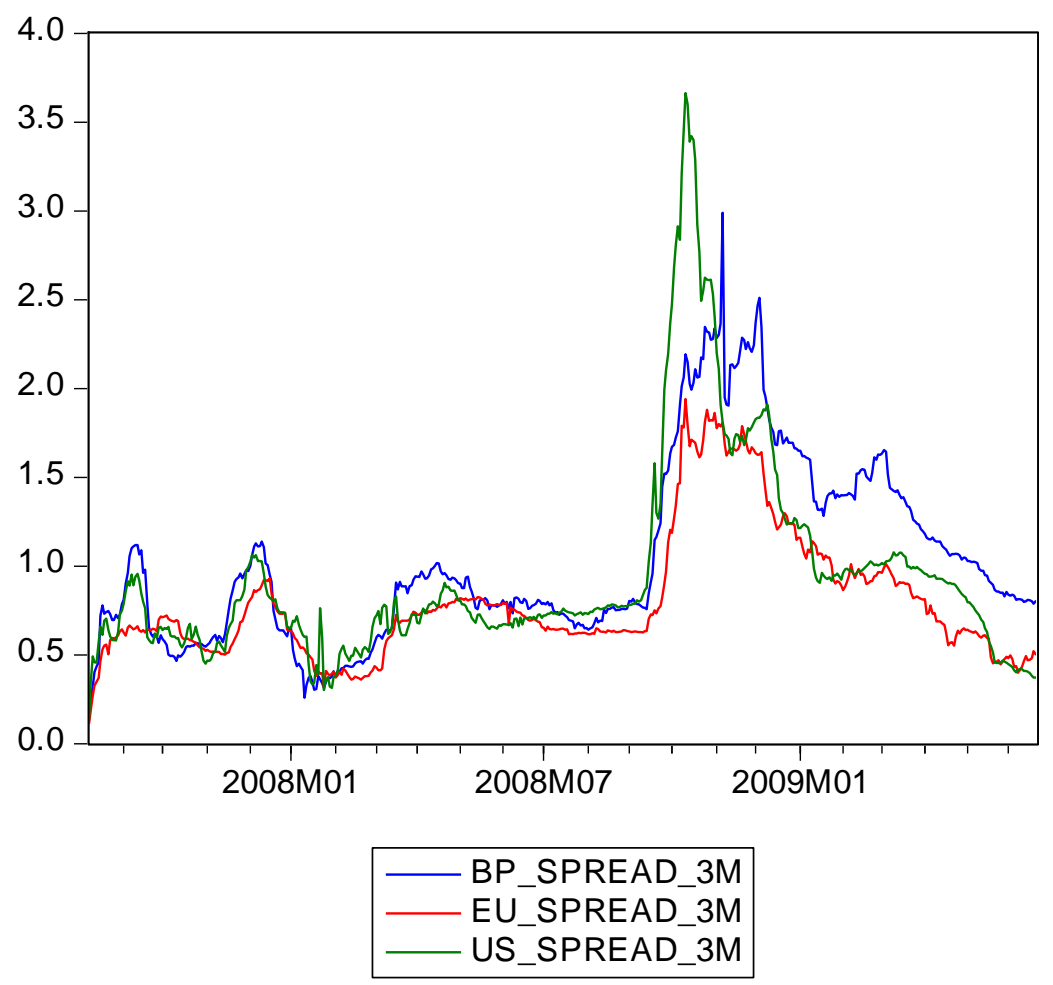

